\title{
INCORPORATION OF RATING PARAMETERS INTO THE PERPETUITY LIMIT OF THE BRUSOV-FILATOVA-OREKHOVA MODERN THEORY OF CAPITAL STRUCTURE
}

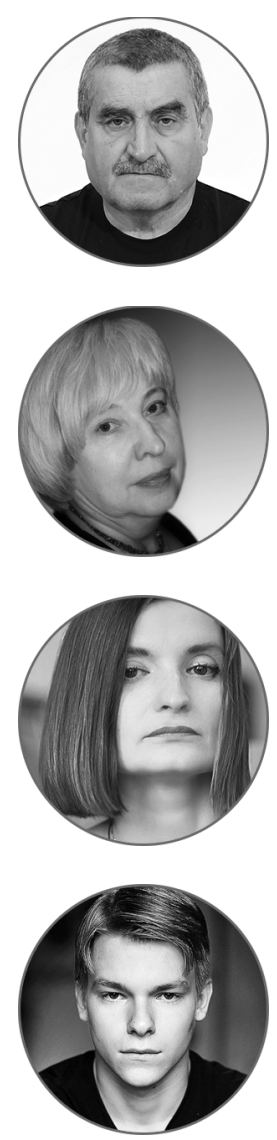

\section{Article history:}

Received 4 August 2017 Received in revised form 28 August 2017

Accepted 21 September 2017

Translated 1 November 2017

Available online 14 December 2017

JEL classification: $\mathrm{G} 24, \mathrm{G} 32$

Keywords: rating, rating methodology, Brusov-Filatova-Orekhova theory, BFO theory, coverage ratio, leverage ratio

\section{Petr N. BRUSOV}

Financial University under Government of Russian Federation, Moscow, Russian Federation pnb1983@yahoo.com

\section{Tat'yana V. FILATOVA}

Financial University under Government of Russian Federation, Moscow, Russian Federation tvfilatova@fa.ru

\section{Natal'ya P. OREKHOVA}

Southern Federal University, Rostov-on-Don, Russian Federation fet_mir@bk.ru

\section{Veniamin L. KULIK}

Financial University under Government of Russian Federation, Moscow, Russian Federation venya.kulik@mail.ru

\begin{abstract}
Importance The research focuses on the existing systems of rating, respective methodologies and weaknesses of these methods.

Objectives We modify the methodology embedded into the existing rating systems and devise a brand new approach based on the appropriate application of discounting to cash flows, use of rating ratios while discounting, correct assessment of discount rates in line with financial ratios.

Methods The research deals with the perpetuity limit of the Brusov-Filatova-Orekhova modern theory of capital cost and capital structure. We also rely upon the modified theory for rating purposes and ratios.

Results We modify the methodology of the existing rating systems and devise an absolutely new approach to it. Conclusions and Relevance Modifying the rating methodology, we make our own assessments more accurate and unbiased. Using the toolkit of the developed theories, we reach new horizons of the rating practice since it enables the rating segment to predominantly use quantitative methods. The proposed approach should be applied by all rating agencies in assessing the creditworthiness of issuers.
\end{abstract}

Please cite this article as: Brusov P.N., Filatova T.V., Orekhova N.P., Kulik V.L. Incorporation of Rating Parameters into the Perpetuity Limit of 468 


\section{Introduction}

In 2015, the leading rating agencies (RA) (Big Three Standard \& Poor's, Fitch and Moody's) downgraded the sovereign credit rating of Russia to non-investable, or junk status (BB+).

The sovereign credit rating decline has severe repercussions for the country, apart from tangible moral damage, and dramatically adverse effects. Foreign investors cannot make financial injections into non-investable economies, thus decreasing or even curbing foreign investment in the economy.

Are the credit ratings objective or politically biased, as the Russian Ministry of Finance reckons?

Can the Big Three ratings be essentially objective as well as ones provided by the other agencies (existing or newly established rating agencies, including European, Russian-Chinese, national, BRICS ones, etc.)? To answer this question, we should be cognizant of the methods rating agencies use to compute, assess, and analyze. However, this is a closely guarded secret. Rating agencies are extremely persistent in keeping their secrets even if they are threatened by multi-billion sanctions. For example, in August 2011, having downgraded the U.S. sovereign credit rating, Standard \& Poor's caused the collapse of markets. Threatening with serious sanctions, a representative of the U.S. Department of the Treasury required S\&P to disclose their methods of analysis but even this pressure did not make them do it. Thus, rating agencies are in fact a kind of black boxes, with the information about their methods being almost unavailable.

\section{The Closed Nature of Rating Agencies}

Rating agencies are so closed systems due to several reasons:

\footnotetext{
${ }^{\dagger}$ For the source article, please refer to: Брусов П.Н., Филатова Т.В. Орехова Н.П., Кулик В.Л. Инкорпорирование параметров, используемых в рейтинговании, в перпетуитетный предел современной теории структуры капитала Брусова-ФилатовойОреховой. Финансы и кредит. 2017. Т. 23. Вып. 40. С. 2378-2397. URL: https://doi.org/10.24891/fc.23.40.2378
}

1) they preserve their know how. Rating agencies gain rather high earnings from ratings they release (mostly from issuers). That is why they are reluctant to disseminate their methodologies;

2) they avoid public speculations on their ratings, including the ranked entity (issuer). It is very convenient behavior since rating agencies a priori protect themselves from any criticism;

3) as their methodologies are not controlled and analyzed externally, their drawbacks are not subject to critical analysis, thus existing for a very long time.

Playing upon democratic principles, some newly established rating agencies arrange public arguments about draft methodologies and publish only some principles and outlines of a methodology, that is the tip of an iceberg, thus preventing specialists from reviewing its underwater body.

As an illustration of the closed nature of rating agencies, we refer to the way S\&P's CEO behaved after the U.S. sovereign credit rating was downgraded. He left his office but refused to disclose the methodology used. Moreover, S\&P paid USD 1.5 billion to the U.S. Department of the Treasury.

However, even in such a situation of closedness, relying on knowledge and understanding of the existing evaluation methods, it is still possible to analyze, in some way or another, operations and conclusions of rating agencies. Rating agencies cannot use methods that are different from those ones leading economists and financiers have elaborated by the time.

The cost of corporate capital and capitalization assessed respectively are the most critical values used to make ratings. Assessments of the indicators are used to rank both particular companies and States. After S\&P decreased the sovereign credit rating of the USA, the U.S. Department of the Treasury blamed them for a mistake worth USD 
2 trillion, while the Security and Exchange Commission intended to scrutinize the S\&P's rating model. Where is the truth?

\section{The Use of Discounting in Rating}

Despite their extensiveness and detailed approach, the existing methodologies have a lot of drawbacks. As for one of the considerable drawbacks of all the existing rating methodologies, they fail to use discounting or use it in a limited way. Even in those rare cases when discounting is applied, it is not quite properly done because the discount rate is chosen incorrectly.

In discounting, the timing factor shall be obviously used since it relates to the time value of money. Financial aspects of rating are based on the comparison of proceeds and the debt and interests. Whereas the time of yields and repayment of the principal and interests differs, the comparison of yields with the principal and interests absolutely necessitates the use of discounting to assign credit ratings to issuers.

In this respect, the question of the discount rate rises. This issue has always been dominant and challenging in finance [1-28], i.e. corporate finance, investment, especially business valuation, where even a slight change in the discount rate substantially modifies the company's capitalization (mala fide appraisers make use of it to artificially declare companies as bankrupt). The discount rate is especially important for purposes of ranking, assigning ratings to issuers and forecasting.

\section{Incorporating Parameters Used in Ratings into Modern Theories of Capital Structure}

In this article we propose a brand new approach to the rating methodology, the key aspect of which is adequate usage of cash flow discounting that the existing rating methodologies almost omit. It is the first time the discounting involves rating ratios.

For this purpose, rating ratios (financial ratios) were incorporated for the first time into the BrusovFilatova-Orekhova modern theory of capital structure (BFO theory) (first of all, into its perpetuity limit) [1].
Constituting various ratios (direct or inverse) of generated income to the principal and interests, financial ratios play a significant role in determining the creditworthiness of issuers. We mean such ratios, as DCF/Debt, FFO/Debt, CFO/Debt, FOCF/Debt, FFO/cash interest, EBITDA/interest, Interests/EBITDA, Debt/EBITDA and so on.

It is important to introduce rating ratios into the BFO modern theory of capital structure and its perpetuity limits - the Modigliani-Miller theory so that it could be used as a robust tool to discount cash flows at correct discount rates. The BFO theory contributes to adequate assessment of the Weighted Average Cost of Capital (WACC) and its equity cost $k_{e}$ applied to discount cash flows.

Tools of the well developed theories open up new horizons for the rating practice. The tools enable the rating practice to move from qualitative methods to the prevalence of quantitative ones in rating, thus definitely enhancing the quality and accuracy of ratings.

Currently, rating agencies apply financial ratios only directly, while the new methodology helps determine the correct values of discount rates (WACC and $k_{e}$ ) used to discount cash flows in line with the payment schedule and forecasting purposes, provided that the values of those ratios are known (and the parameter $k_{0}$ ).

It entailed the modification of the BFO theory and its perpetuity limit - the Modigliani-Miller theory since the concept of leverage in financial management as the debt-to-equity ratio differs from leverage in rating, that is, the ratio of a loan, loan interests to earnings. Inverse ratios (various earnings-to-loan/ loan interests) are also used, the so called coverage ratios (principal, interests).

We introduce additional ratios that contribute to a more thorough description of the issuer's ability to repay debts and loan interests.

Hence, we build a bridge between discount rates used to discount various cash flows and ratios used in rating. We devise an algorithm for determining discount rates with rating ratios being given. 
We afterwards propose two models (one-period and multi-period ones) designed to evaluate the issuers' creditworthiness through discounting.

\section{Models for Evaluating the Issuers' Creditworthiness Through Discounting}

\section{One-Period Model}

The one-period model is expressed with the following formula (Fig. 1):

$$
\begin{aligned}
& C F(1+i)^{t_{2}-t} \geq D+k_{d} D(1+i)^{t_{2}-t_{1}} ; \\
& C F(1+i)^{t_{2}-t} \geq D\left[1+k_{d} D(1+i)^{t_{2}-t_{1}}\right],
\end{aligned}
$$

where $C F$ is the amount of income for the period;

$D$ is the amount of a loan;

$t_{1} t_{1}, t_{2}$ are moments of yields, repayment of the principal and interests respectively;

$i$ is the discount rate;

$k_{d}$ is the interest rate on a loan;

$k_{d} D$ are interests on a loan in kind (monetary value).

\section{Multi-Period Model}

The one-period model for the issuer's creditworthiness evaluation, which implies the discounting of cash flows, can be generalized and adjusted for a more interesting multi-period case.

The multi-period model is expressed with the following inequality:

$$
C F_{j}(1+i)^{t_{2 j}-t_{j}} \geq D_{j}\left[1+k_{d j}(1+i)^{t_{t_{j}}-t_{1_{j}}}\right],
$$

where $j=1,2, \ldots, n$ ( $n$ is the number of periods);

$C F_{j}$ is the amount of income for the $j$-period;

$D_{j}$ is the amount of a loan in the $j$-period;

$t_{j}, t_{1 j}, t_{2 j}$ are moments of yields, repayment of the principal and interests in the j-period respectively;

$i$ is the common discount rate for all the periods (though, if needed, the special discount rate $i_{j}$ for the $j$-period can be introduced);

$k_{d j}$ is the interest rate on a loan in the $j$-period;

$k_{d j} D_{j}$ are interests on a loan in kind (monetary value) in the $j$-period.
The same inequality is also present:

$$
\sum_{j} C F_{j}(1+i)^{t_{2_{j}}-t_{j}} \geq \sum_{j} D_{j}\left[1+k_{d j}(1+i)^{t_{2_{j}}-t_{1 j}}\right] .
$$

There may be several options to deal with the models.

1. The issuer's creditworthiness can be verified if $C F_{j}$, $D_{j}, t_{j}, t_{1 j}, t_{2 j}, k_{d j}$ are available and the discount rate $i$ is assessed with the method given further.

2. If $D_{j,} t_{j,} t_{1 j}, t_{2 j}, k_{d j}$ are given, it is possible to determine which income $C F_{j}$ the issuer will need to ensure its creditworthiness.

3. If $C F_{j}, t_{j}, t_{1 j}, t_{2 j}$ are given, it is possible to determine the tolerable level of debt financing (including the amount of the loan $D_{j}$ and the interest rate on loans $k_{d j}$ ) that preserves the issuer's creditworthiness.

\section{The Theory of Incorporating Rating Parameters into Modern Theories of Capital Structure}

We introduce parameters used in rating into the perpetuity limit of the BFO modern theory of capital structure [1] - the Modigliani-Miller theorem [4-6] for the first time.

We suggest reviewing two types of rating ratios, i.e. coverage and leverage ones.

We begin with the coverage ratios in relation to the principal and respective interests.

\section{Coverage Ratios}

\section{Debt-Service Coverage Ratio}

We are going to focus on three types of coverage ratios: debt-service coverage, interest coverage and debt-and-interest coverage ratio. It is worth mentioning that we present the latter type for the first time in order to provide a more comprehensive description of the issuer's ability to repay its debts and interests on them.

Hereinafter we put it as $i_{1}=C F / D$.

According to the Modigliani-Miller theorem in case of corporate taxes [4-6], the capitalization of the levered company (using debt financing) $V_{L}$ equals that of the unlevered company (abstaining from debt 
financing) $V_{0}$ times the value of tax shield for an infinite period of time $D t$.

$$
V_{L}=V_{0}+D t \text {. }
$$

Inserting the capitalization expressions through earnings per period $C F$, we arrive at the following system:

$$
\begin{aligned}
& \frac{C F}{W A C C}=\frac{C F}{k_{0}}+D t ; \\
& \frac{i_{1}}{W A C C}=\frac{i_{1}}{k_{0}}+t ; \\
& W A C C=i_{1} \frac{k_{0}}{i_{1}+t k_{0}} .
\end{aligned}
$$

This ratio may be used to evaluate such rating parameters as DCF/Debt, FFO/Debt, CFO/Debt, FOCF/Debt, etc.

Hereinafter we apply the following denotations:

EBITDA stands for earnings before interests, taxes, depreciation and amortization;

EBITDAR stands for earnings before interests, taxes, depreciation, amortization and restructuring or rent costs;

FFO stands for operating cash flows before changes in working capital;

Debt is the outstanding amount;

CFF is cash flows from financing activities;

FCF is free cash flow;

NFCF is net cash flow;

$D C F$ is discounted cash flow;

CFO is cash flow from operations.

\section{Interest Coverage Ratio}

$$
\begin{aligned}
& V_{L}=V_{0}+D t . \\
& \frac{C F}{W A C C}=\frac{C F}{k_{0}}+D t ; \\
& \frac{i_{2}}{W A C C}=\frac{i_{2}}{k_{0}}+\frac{t}{k_{d}} ; \\
& W A C C=\frac{i_{2} k_{0} k_{d}}{i_{2} k_{d}+t k_{0}} .
\end{aligned}
$$

It is given here as $i_{2}=C F / k_{d} D$.
This ratio can be used to evaluate such rating parameters as FFO/cash interests, EBITDA/interest, etc.

\section{Debt-and-Interest Coverage Ratio (A New Parameter)}

$$
\begin{aligned}
& V_{L}=V_{0}+D t . \\
& \frac{C F}{W A C C}=\frac{C F}{k_{0}}+D t ; \\
& \frac{i_{3}}{W A C C}=\frac{i_{3}}{k_{0}}+\frac{t}{1+k_{d}} ; \\
& W A C C=\frac{i_{3} k_{0}\left(1+k_{d}\right)}{i_{3}\left(1+k_{d}\right)+t k_{0}} .
\end{aligned}
$$

Here it is expressed as $i_{3}=\frac{C F}{D\left(1+k_{d}\right)}$.

This ratio can be applied to evaluate such rating parameters as

\section{Leverage Ratios}

\section{The Leverage Ratio of the Loan (Debt)}

$$
\begin{aligned}
& l_{1}=D / C F \\
& \frac{C F}{W A C C}=\frac{C F}{k_{0}}+D t \\
& \frac{1}{W A C C}=\frac{1}{k_{0}}+l_{1} t \\
& W A C C=\frac{k_{0}}{1+t l_{1} k_{0}} .
\end{aligned}
$$

This ratio can be applied to evaluate such rating parameters as Debt/EBITDA, etc.

\section{The Leverage Ratio of Loan Interests}

Here it is $l_{2}=k_{d} D / C F$.

$$
\begin{aligned}
& \frac{C F}{W A C C}=\frac{C F}{k_{0}}+D t ; \\
& \frac{1}{W A C C}=\frac{1}{k_{0}}+\frac{l_{2} t}{k_{d}} ; \\
& W A C C=\frac{k_{0} k_{d}}{k_{d}+t l_{2} k_{0}} .
\end{aligned}
$$

This ratio can be applied to evaluate such rating parameters as Interests/EBITDA, etc. 


\section{The Leverage Ratio of the Debt and Interests}

Assume that $l_{2}=D\left(1+k_{d}\right) / C F$.

$$
\begin{aligned}
& \frac{C F}{W A C C}=\frac{C F}{k_{0}}+D t ; \\
& \frac{1}{W A C C}=\frac{1}{k_{0}}+\frac{l_{3} t}{1+k_{d}} ; \\
& W A C C=\frac{k_{0}\left(1+k_{d}\right)}{1+k_{d}+t l_{3} k_{0}} .
\end{aligned}
$$

This ratio can be applied to evaluate such rating parameters as Debt + interest/FFO, Debt + interest/EBITDA, etc.

\section{Studying the Dependence of the WACC on Rating Parameters}

We examine how the WACC depends on rating parameters. Assume that $k_{0}=12 \%, k_{d}=6 \%, t=20 \%$. The study concerned really different values of $k_{0}$ and $k_{d}$. Results are essentially similar.

The dependence of the WACC on the parameter $i_{2}$, i.e. the dependence of the Weighted Average Cost of Capital on the interest coverage ratio is given in Table 1 and Fig. 2.

The dependence of the WACC on the parameter $i_{3}$, i.e. the Weighted Average Cost of Capital on the debt-and-interest coverage ratio, is given in Table 2 and Fig. 3.

The dependence of the cost of capital on the debtservice coverage ratio, interest coverage ratio and debt-and-interest coverage ratio is presented in Table 3 and Fig. 4.

A more thorough examination results in the following conclusions.

1. In case of the debt-and-interest ratio in relation to the loan $i_{3}$, the WACC increases and gets saturated quite quickly: with a 20-percent precision if $i_{3}=$ 0.15 , and a 5 -percent precision if $i_{3}=0.5$.

2 . In case of the debt-service coverage ratio $i_{1}$, the WACC grows almost linearly alongside with an increase in the ratio $i_{1}$, and gets saturated if $i_{1}=$ 0.1 .

3. In case of the interest coverage ratio $i_{2}$, the WACC rises at much slower pace, alongside with the ratio $i_{2}$, and gets saturated if $i_{2}$ has higher values: with a 10-percent precision if $i_{2}=4$.

4. We shall note that, as shown in Table 1 and 3, the dependencies of the WACC $\left(i_{1}\right)$ and the WACC $\left(i_{3}\right)$ approximate one another and almost converge in Fig. 4. It results from the low loan interest rate (6 percent). In case of considerable borrowings, the dependencies will differ more noticeably, including graphs.

\section{The Dependence of the Weighted Average Cost of Capital on Leverage Levels $l$}

We analyze the way the Weighted Average Cost of Capital (WACC) depends on the level of leverage $/$ if the following parameters are given:

$k_{0}=12 \% ; k_{d}=6 \% ; t=20 \% ; /$ ranges from 0 to 10 .

Table 4 and Fig. 5 showcase the dependence of the WACC on the leverage ratio of the loan $I_{1}$.

The dependence of the WACC on the leverage ratio of interests on the loan $I_{2}$ is presented in Table 5 and Fig. 6.

The dependence of the WACC on the leverage ratio of interests and principal on the loan $I_{3}$ is presented in Table 6 and Fig. 7.

The dependence of the cost of capital on the leverage ratio of the principal, interest and combination of the principal and interests is presented in Fig. 8.

Having analyzed the dependence of the WACC on the leverage ratio of the principal $l_{1}$, interests on the loan $I_{2}$ and combination of the principal and interests $I_{3}$, we made the following conclusions. In case of all the three ratios $I_{1}, I_{2}, I_{3}$, the WACC decreases as the leverage increases. In case of the leverage ratios $l_{1}$ and $l_{3}$, the WACC drops in a similar way. It declines almost linearly from $k_{0}=$ $12 \%$ if $I_{1,3}=0$, and down to $9.7 \%$ if $I_{1,3}=10$. In case of the leverage ratio of interests on the loan $I_{2}$, the WACC decreases not in a linear way and much faster, shifting from $k_{0}=12 \%$ if $I_{2}=0$ down to $2.4 \%$ if $I_{2}=10$. Thus, the WACC decline point $\left(k_{0}=12 \%\right.$ if $I_{1,2,3}=$ 0 ) and monotonous nature of this decline are common for all the three dependencies of the WACC on the leverage level, while the WACC decreases 
much faster in case of the leverage ratio of interests on the loan $I_{2}$ than it does in cases of $I_{1}$ and $l_{3}$. As seen in Tables 4 and 6, note that the dependencies WACC $\left(I_{1}\right)$ and WACC $\left(I_{3}\right)$ approximate one another and almost coincide in Fig. 8. It results from the low interest rate on the loan (6\%). In case of the expensive borrowing costs, the difference between the dependencies will be more noticeable, including graphs.

\section{How is the Discount Rate Measured?}

In paragraphs below we discuss the algorithm for computing the discount rate, provided that one or several financial ratios are given (coverage ratios or leverage ratios).

The devised method helps measure the discount rate as precisely as possible in the BFO theory of capital structure or its perpetuity limit.

\section{The Use of One Ratio}

If one financial ratio (coverage ratio or leverage ratio) is known, the discount rate measurement algorithm implies the following steps in order to discount cash flows as part of the issuer's creditworthiness evaluation:

1) we determine the parameter $k_{0}$. Please note that A.P. Brusova's methods for determining the parameter $k_{0}$ (WACC under zero leverage) [2] become one of the cornerstones in this part of the rating methodology;

2) having the values of $k_{0}, k_{d}$ and $t$ and applying the devised methods, we construct a curve reflecting the dependence of the WACC on financial ratios (coverage ratio or leverage ratio), i.e. $W A C C(i)$ or WACC(l);

3) having the coverage ratio $\left(i_{0}\right)$ or leverage ratio $\left(I_{0}\right)$, we use the curves $W A C C(i)$ or $W A C C(I)$ to gauge the $\operatorname{WACC}\left(i_{0}\right)$ or $\operatorname{WACC}\left(I_{0}\right)$, which constitute the discount rate.

In our further researches, we will forge a similar method based on the BFO theory for arbitrary lifetime companies.

\section{The Use of Several Ratios}

If several financial ratios (say, $m$ coverage ratios $\left(i_{j}\right)$ and $n$ leverage ratios $\left(I_{k}\right)$ ) are in place, the algorithm for measuring the discount rate is modified in the following way so as to discount cash flows as part of the issuer's creditworthiness evaluation:

1) based on the given algorithm, we find $m$ values of the $\operatorname{WACC}\left(i_{0 j}\right)$ and $n$ values of $\operatorname{WACC}\left(I_{0 k}\right)$;

2) we compute the mean WACC using the following formula:

$$
\begin{gathered}
\text { WACC }_{a v}= \\
=\frac{1}{m+n}\left[\sum_{j=1}^{m} W A C C\left(i_{0 j}\right)+\sum_{k=1}^{n} W A C C\left(l_{0 k}\right)\right] .
\end{gathered}
$$

It is the mean $W A C C_{a v}$ that represents the required discount rate used to discount cash flows in rating.

\section{Conclusions}

The article proposes a new approach to the rating methodology, the key factor of which is the appropriate use of cash flow discounting. The existing rating methodologies almost neglect it. It is the first time when the discounting is performed in line with rating ratios.

For this purpose, we incorporated the rating ratios (financial ratios) into the modern theory of capital structure by Brusov - Filatova - Orekhova (initially into its perpetuity limit). On the one hand, it helps involve a robust toolkit of the theory into the rating practice, but, on the other hand, it ensures the use of correct discount rates to discount cash flows.

We proposed two models for the issuer's creditworthiness evaluation: one-period and multiperiod ones. They help 1) verify the issuer's creditworthiness if $C F_{j}, D_{j}, t_{j}, t_{1 j}, t_{2 j}, k_{d j}$ are known, and determine the discount rate WACC $_{a v}$ with the devised method; 2 ) based on $D_{j}, t_{j}, t_{1 j}, t_{2 j}, k_{d j}$, determine which income $C F_{j}$ the issuer will need to remain solvent; 3 ) based on $C F_{j}, t_{j}, t_{1 j}, t_{2 j}$, assess the tolerable level of the issuer's debt financing level (including values of the principal $D_{j}$ and the interest rate on loans $k_{d j}$ ) so as to preserve its solvency.

The article sets out our method for determining the discount rate in line with the found rating ratios.

Thus, the above findings enable us to build a bridge between fundamental theories of corporate capital structure and rating methodologies. 
The toolkit of the well developed theories opens new horizons for the rating practice, which can subsequently move from the prevalence of qualitative methods for creditworthiness evaluation to quantitative ones in rating, thus enhancing the quality and accuracy of ratings.

\section{Figure 1}

The one-period model

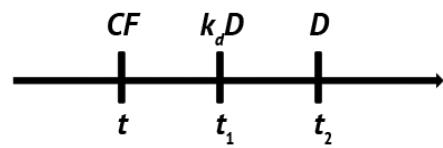

Source:Authoring

\section{Table 1}

Dependence of the WACC on the parameter $i_{1}$

\begin{tabular}{lllll}
\hline $\boldsymbol{t}$ & $\boldsymbol{i}_{\mathbf{1}}$ & $\boldsymbol{k}_{\mathbf{0}}$ & $\boldsymbol{K}$ & $\boldsymbol{W}$ \\
\hline 0.2 & 0 & 0.12 & 0.06 & 0 \\
\hline 0.2 & 1 & 0.12 & 0.06 & 0.1171875 \\
\hline 0.2 & 2 & 0.12 & 0.06 & 0.1185771 \\
\hline 0.2 & 3 & 0.12 & 0.06 & 0.1190476 \\
\hline 0.2 & 4 & 0.12 & 0.06 & 0.1192843 \\
\hline 0.2 & 5 & 0.12 & 0.06 & 0.1194268 \\
\hline 0.2 & 6 & 0.12 & 0.06 & 0.1195219 \\
\hline 0.2 & 7 & 0.12 & 0.06 & 0.11959 \\
\hline 0.2 & 8 & 0.12 & 0.06 & 0.1196411 \\
\hline 0.2 & 9 & 0.12 & 0.06 & 0.1196809 \\
\hline 0.2 & 10 & 0.12 & 0.06 & 0.1197127 \\
\hline
\end{tabular}

Source:Authoring

\section{Figure 2}

Dependence of the WACC on the Debt Service Coverage Ratio $i_{1}$

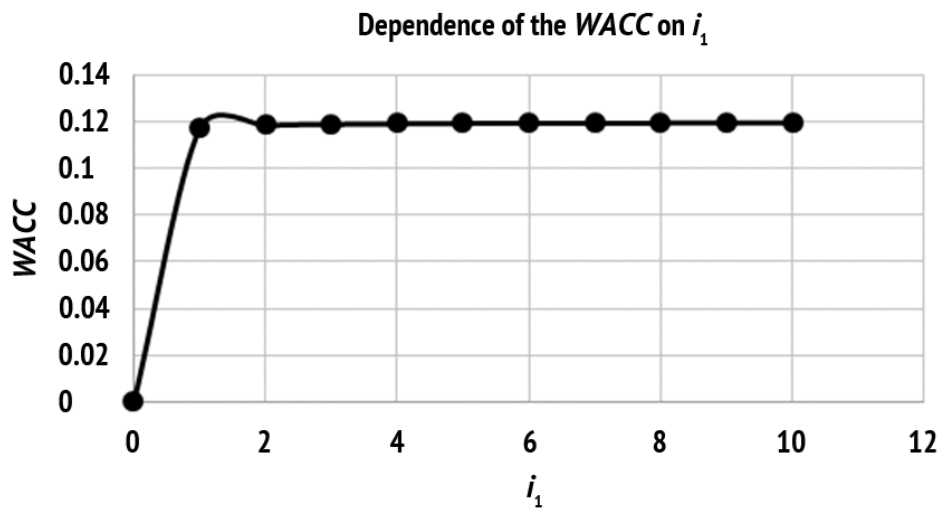

Source: Authoring 


\section{Table 2}

Dependence of the WACC on the parameter $i_{2}$

\begin{tabular}{lllll}
\hline $\boldsymbol{t}$ & $\boldsymbol{i}_{\mathbf{2}}$ & $\boldsymbol{k}_{\mathbf{0}}$ & $\boldsymbol{k} \boldsymbol{d}$ & $\boldsymbol{W A C C}$ \\
\hline 0.2 & 0 & 0.12 & 0.06 & 0 \\
\hline 0.2 & 1 & 0.12 & 0.06 & 0.085714 \\
\hline 0.2 & 2 & 0.12 & 0.06 & 0.1 \\
\hline 0.2 & 3 & 0.12 & 0.06 & 0.105882 \\
\hline 0.2 & 4 & 0.12 & 0.06 & 0.109091 \\
\hline 0.2 & 5 & 0.12 & 0.06 & 0.111111 \\
\hline 0.2 & 6 & 0.12 & 0.06 & 0.1125 \\
\hline 0.2 & 7 & 0.12 & 0.06 & 0.113514 \\
\hline 0.2 & 8 & 0.12 & 0.06 & 0.114286 \\
\hline 0.2 & 9 & 0.12 & 0.06 & 0.114894 \\
\hline 0.2 & 10 & 0.12 & 0.06 & 0.115385 \\
\hline
\end{tabular}

Source: Authoring

\section{Figure 3}

Dependence of the WACC on the interest coverage ratio $i_{2}$

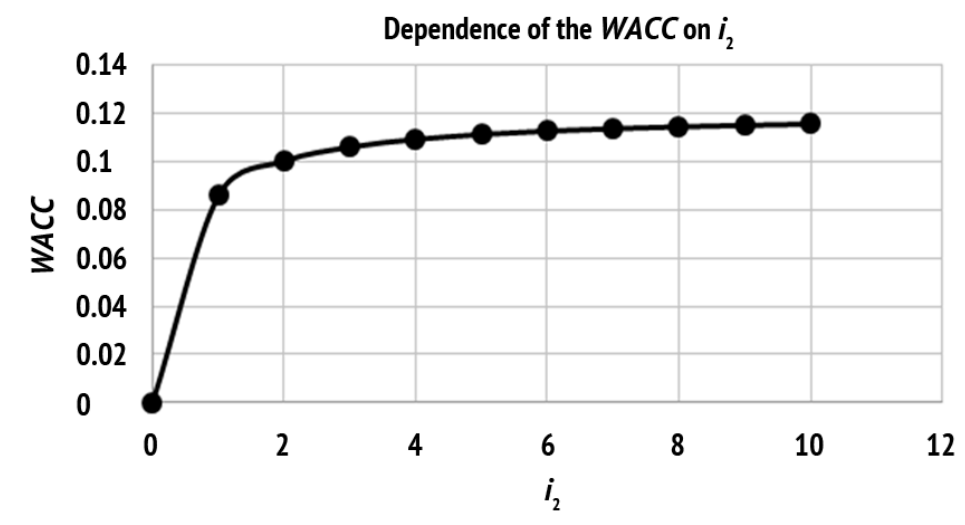

Source: Authoring the Brusov-Filatova-Orekhova Modern Theory of Capital Structure. Digest Finance, 2017, vol. 22, iss. 4, pp. 468-482. 


\section{Table 3}

Dependence of the WACC on the parameter $i_{3}$

\begin{tabular}{lllll}
\hline $\boldsymbol{t}$ & $\boldsymbol{i}_{\boldsymbol{3}}$ & $\boldsymbol{k}_{\mathbf{0}}$ & $\boldsymbol{k d}$ & $\boldsymbol{W A C C}$ \\
\hline 0.2 & 0 & 0.12 & 0.06 & 0 \\
\hline 0.2 & 1 & 0.12 & 0.06 & 0.1173432 \\
\hline 0.2 & 2 & 0.12 & 0.06 & 0.1186567 \\
\hline 0.2 & 3 & 0.12 & 0.06 & 0.1191011 \\
\hline 0.2 & 4 & 0.12 & 0.06 & 0.1193246 \\
\hline 0.2 & 5 & 0.12 & 0.06 & 0.1194591 \\
\hline 0.2 & 6 & 0.12 & 0.06 & 0.1195489 \\
\hline 0.2 & 7 & 0.12 & 0.06 & 0.1196131 \\
\hline 0.2 & 8 & 0.12 & 0.06 & 0.1196613 \\
\hline 0.2 & 9 & 0.12 & 0.06 & 0.1196989 \\
\hline 0.2 & 10 & 0.12 & 0.06 & 0.1197289
\end{tabular}

Source. Authoring

\section{Figure 4}

Dependence of the WACC on the debt-and-interests coverage ratio $i_{3}$

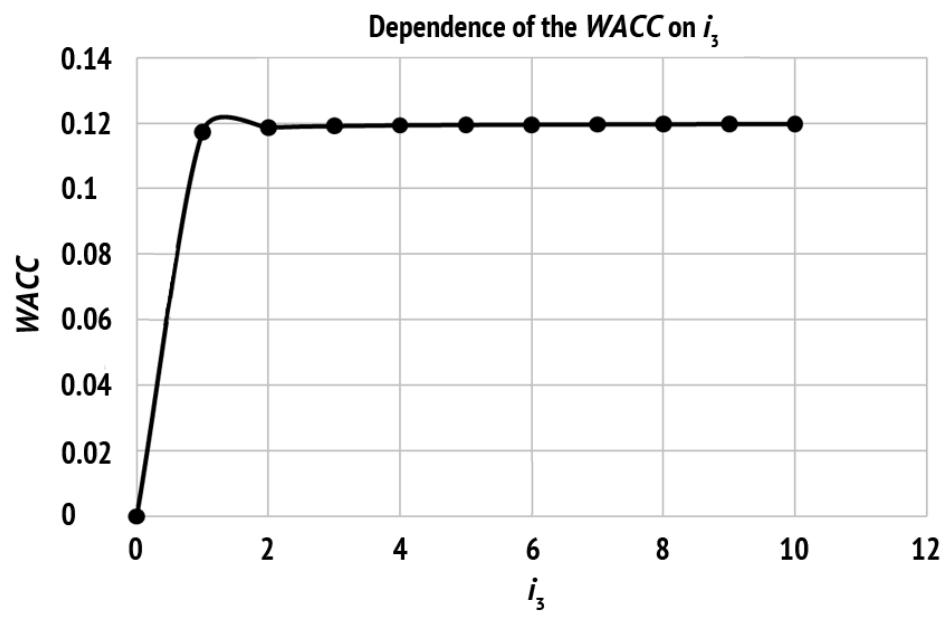

Source. Authoring 


\section{Figure 5}

Dependence of the WACC on the debt coverage ratio, interest coverage ratio and debt-and-interest ratio

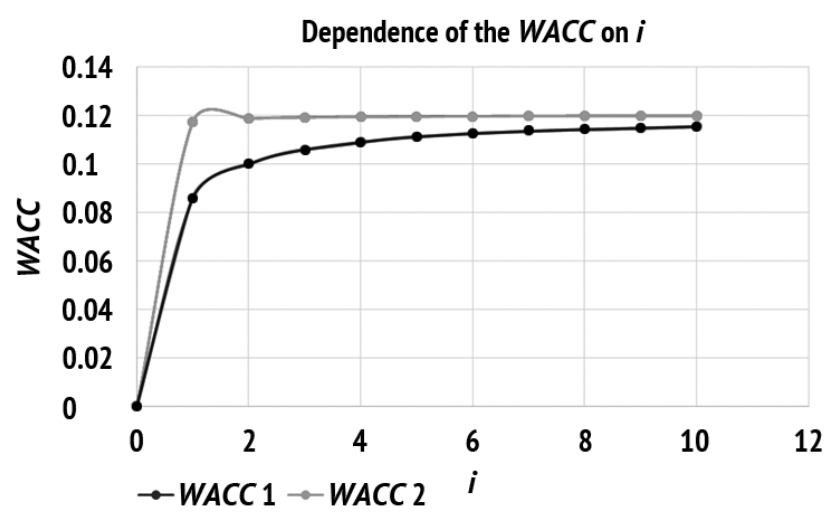

Source: Authoring

\section{Table 4}

Dependence of the WACC on the parameter $l_{1}$

\begin{tabular}{lllll}
\hline $\boldsymbol{t}$ & $\boldsymbol{l}_{\mathbf{1}}$ & $\boldsymbol{k}_{\mathbf{0}}$ & $\boldsymbol{k d}$ & $\boldsymbol{W A C C}$ \\
\hline 0.2 & 0 & 0.12 & 0.06 & 0.12 \\
\hline 0.2 & 1 & 0.12 & 0.06 & 0.117188 \\
\hline 0.2 & 2 & 0.12 & 0.06 & 0.114504 \\
\hline 0.2 & 3 & 0.12 & 0.06 & 0.11194 \\
\hline 0.2 & 4 & 0.12 & 0.06 & 0.109489 \\
\hline 0.2 & 5 & 0.12 & 0.06 & 0.107143 \\
\hline 0.2 & 6 & 0.12 & 0.06 & 0.104895 \\
\hline 0.2 & 7 & 0.12 & 0.06 & 0.10274 \\
\hline 0.2 & 8 & 0.12 & 0.06 & 0.100671 \\
\hline 0.2 & 9 & 0.12 & 0.06 & 0.098684 \\
\hline 0.2 & 10 & 0.12 & 0.06 & 0.096774 \\
\hline
\end{tabular}

Source: Authoring 


\section{Figure 6}

Dependence of the WACC on the leverage ratio of the debt $l_{1}$

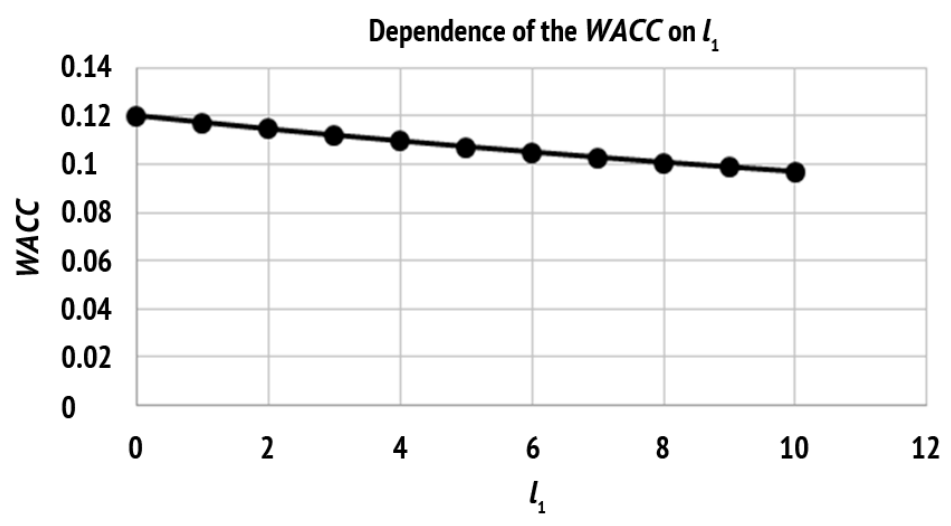

Source: Authoring

Table 5

Dependence of the WACC on the parameter $l_{2}$

\begin{tabular}{lllll}
\hline $\boldsymbol{t}$ & $\boldsymbol{\boldsymbol { l }}$ & $\boldsymbol{k}_{\mathbf{0}}$ & $\boldsymbol{k} \boldsymbol{\text { WACC }}$ \\
\hline 0.2 & 0 & 0.12 & 0.06 & 0.12 \\
\hline 0.2 & 1 & 0.12 & 0.06 & 0.085714 \\
\hline 0.2 & 2 & 0.12 & 0.06 & 0.066667 \\
\hline 0.2 & 3 & 0.12 & 0.06 & 0.054545 \\
\hline 0.2 & 4 & 0.12 & 0.06 & 0.046154 \\
\hline 0.2 & 5 & 0.12 & 0.06 & 0.04 \\
\hline 0.2 & 6 & 0.12 & 0.06 & 0.035294 \\
\hline 0.2 & 7 & 0.12 & 0.06 & 0.031579 \\
\hline 0.2 & 8 & 0.12 & 0.06 & 0.028571 \\
\hline 0.2 & 9 & 0.12 & 0.06 & 0.026087 \\
\hline 0.2 & 10 & 0.12 & 0.06 & 0.024 \\
\hline
\end{tabular}

Source:Authoring

Figure 7

Dependence of the WACC on the leverage ratio of interests on the loan $l_{2}$

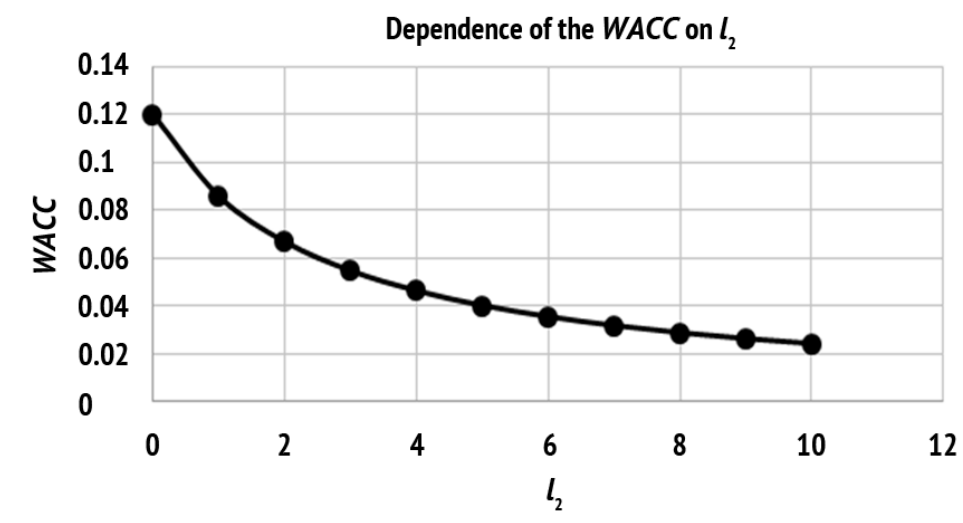

Source: Authoring

Please cite this article as: Brusov P.N., Filatova T.V., Orekhova N.P., Kulik V.L. Incorporation of Rating Parameters into the Perpetuity Limit of the Brusov-Filatova-Orekhova Modern Theory of Capital Structure. Digest Finance, 2017, vol. 22, iss. 4, pp. 468-482. https://doi.org/10.24891/df.22.4.468 


\section{Table 6}

Dependence of the WACC on the parameter $l_{3}$

\begin{tabular}{lllll}
\hline $\boldsymbol{t}$ & $\boldsymbol{l}_{\boldsymbol{B}}$ & $\boldsymbol{k}_{\mathbf{0}}$ & $\boldsymbol{k d}$ & $\boldsymbol{W A C C}$ \\
\hline 0.2 & 0 & 0.12 & 0.06 & 0.12 \\
\hline 0.2 & 1 & 0.12 & 0.06 & 0.117353 \\
\hline 0.2 & 2 & 0.12 & 0.06 & 0.114819 \\
\hline 0.2 & 3 & 0.12 & 0.06 & 0.112393 \\
\hline 0.2 & 4 & 0.12 & 0.06 & 0.110068 \\
\hline 0.2 & 5 & 0.12 & 0.06 & 0.107836 \\
\hline 0.2 & 6 & 0.12 & 0.06 & 0.105693 \\
\hline 0.2 & 7 & 0.12 & 0.06 & 0.103634 \\
\hline 0.2 & 8 & 0.12 & 0.06 & 0.101654 \\
\hline 0.2 & 9 & 0.12 & 0.06 & 0.099747 \\
\hline 0.2 & 10 & 0.12 & 0.06 & 0.097911 \\
\hline
\end{tabular}

Source: Authoring

\section{Figure 8}

Dependence of the WACC on the leverage ratio of the principal and interests on the loan $l_{3}$

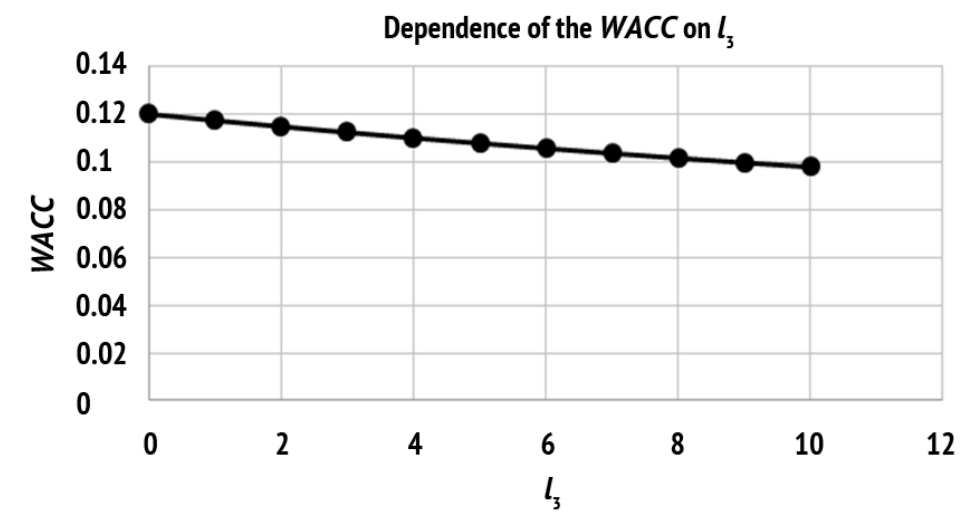

Source:Authoring

\section{Figure 9}

Dependence of the WACC on the leverage level of the principle, interests and their combination

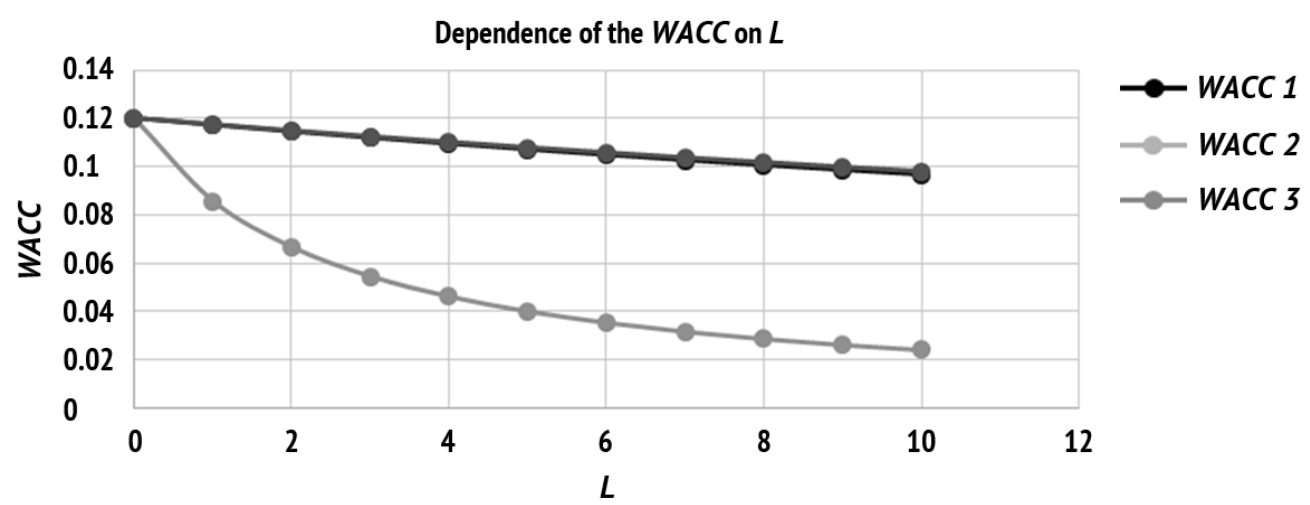

Source:Authoring the Brusov-Filatova-Orekhova Modern Theory of Capital Structure. Digest Finance, 2017, vol. 22, iss. 4, pp. 468-482. https://doi.org/10.24891/df.22.4.468 


\section{Acknowledgments}

The research was supported by the Russian Foundation for Basic Research as part of Scientific Project No. 17-06-00251A.

\section{References}

1. Brusov P.N., Filatova T.V., Orehova N.P., Eskindarov M.A. Modern Corporate Finance, Investment and Taxation. Springer International Publishing, 2015, 368 p.

2. Brusova A.P. [Comparison of the methods for assessment of weighted average cost of capital and the value of its equity]. Finansovaya analitika: problemy i resheniya = Financial Analytics: Problems and Solutions, 2011, no. 34, pp. 36-42. URL: https://cyberleninka.ru/article/v/sravnenie-metodov-otsenkisrednevzveshennoy-stoimosti-kapitala-kompanii-i-stoimosti-ee-sobstvennogo-kapita (In Russ.)

3. Myers S.C. Capital Structure. Journal of Economic Perspectives, 2001, vol. 15, iss. 2, pp. 81-102. URL: https://doi.org/10.1257/jep.15.2.81

4. Modigliani F., Miller M.H. The Cost of Capital, Corporate Finance and the Theory of Investment. The American Economic Review, 1958, vol. 48, no. 3, pp. 261-297.

5. Modigliani F., Miller M.H. Corporate Income Taxes and the Cost of Capital: A Correction. The American Economic Review, 1963, vol. 53, no. 3, pp. 433-443.

6. Modigliani F., Miller M.H. Some Estimates of the Cost of Capital to the Electric Utility Industry 1954-1957. The American Economic Review, 1966, vol. 56, no. 3, pp. 333-391.

7. Baker M., Wurgler J. Market Timing and Capital Structure. The Journal of Finance, 2002, vol. 57, iss. 1, pp. 1-32. URL: https://doi.org/10.1111/1540-6261.00414

8. Beattie V., Goodacre A., Thomson S.J. Corporate Financing Decisions: UK Survey Evidence. Journal of Business Finance \& Accounting, 2006, vol. 33, iss. 9-10, pp. 1402-1434.

URL: https://doi.org/10.1111/j.1468-5957.2006.00640.x

9. Bikhchandani S., Hirshleifer D., Welch I. Learning from the Behavior of Others: Conformity, Fads, and Informational Cascades. The Journal of Economic Perspectives, 1998, vol. 12, no. 3, pp. 151-170.

URL: https://doi.org/10.1257/jep.12.3.151

10. Brennan M., Schwartz E.S. Corporate Income Taxes, Valuation, and the Problem of Optimal Capital Structure. The Journal of Business, 1978, vol. 51, iss. 1, pp. 103-114.

11. Brennan M.J., Schwartz E.S. Optimal Financial Policy and Firm Valuation. The Journal of Finance, 1984, vol. 39, iss. 3, pp. 593-607. URL: https://doi.org/10.1111/j.1540-6261.1984.tb03647.x

12. Dittmar A., Thakor A. Why Do Firms Issue Equity? The Journal of Finance, 2007, vol. 62, iss. 1, pp. 1-54. URL: https://doi.org/10.1111/j.1540-6261.2007.01200.x

13. Drobetz W., Pensa P., Wanzenried G. Firm Characteristics and Dynamic Capital Structure Adjustment. URL: http://papers.ssrn.com/sol3/papers.cfm?abstract_id=952268

14. Fama E.F., French K.F. Financing Decisions: Who Issues Stock? Journal of Financial Economics, 2005, vol. 76, iss. 3, pp. 549-582. URL: https://doi.org/10.1016/j.jfineco.2004.10.003

15. Fischer E., Heinkel R., Zechner J. Dynamic Capital Structure Choice: Theory and Tests. The Journal of Finance, 1989, vol. 44, iss. 1, pp. 19-40. URL: https://doi.org/10.2307/2328273 
16. Graham J.R., Harvey C.R. The Theory and Practice of Corporate Finance: Evidence from the Field. Journal of Financial Economics, 2001, vol. 60, iss. 2-3, pp. 187-243.

URL: https://doi.org/10.1016/S0304-405X(01)00044-7

17. Hamada R. Portfolio Analysis, Market Equilibrium, and Corporate Finance. The Journal of Finance, 1969, vol. 24, iss. 1, pp. 13-31. URL: https://doi.org/10.1111/j.1540-6261.1969.tb00339.x

18. Harris M., Raviv A. The Theory of Capital Structure. The Journal of Finance, 1991, vol. 46, iss. 1 , pp. 297-355. URL: https://doi.org/10.1111/j.1540-6261.1991.tb03753.x

19. Hovakimian A., Opler T., Titman S. The Debt-Equity Choice. Journal of Financial and Quantitative Analysis, 2001, vol. 36, iss. 1, pp. 1-24. URL: https://doi.org/10.2307/2676195

20. Hsia C. Coherence of the Modern Theories of Finance. The Financial Review, 1981, vol. 16, iss. 1, pp. 27-42. URL: https://doi.org/10.1111/j.1540-6288.1981.tb01617.x

21. Jalilvand A., Harris R.S. Corporate Behavior in Adjusting to Capital Structure and Dividend Targets: An Econometric Study. The Journal of Finance, 1984, vol. 39, iss. 1, pp. 127-145. URL: https://doi.org/10.1111/j.1540-6261.1984.tb03864.x

22. Jensen M.C., Meckling W.H. Theory of the Firm: Managerial Behavior, Agency Costs, and Ownership Structure. Journal of Financial Economics, 1976, vol. 3, iss. 4, pp. 305-360. URL: https://doi.org/10.1016/0304-405X(76)90026-X

23. Jenter D. Market Timing and Managerial Portfolio Decisions. The Journal of Finance, 2005, vol. 60, iss. 4 , pp. 1903-1949. URL: https://doi.org/10.1111/j.1540-6261.2005.00783.x

24. Korajczyk R.A., Levy A. Capital Structure Choice: Macroeconomic Conditions and Financial Constraints. Journal of Financial Economics, 2003, vol. 68, iss. 1, pp. 75-109. URL: https://doi.org/10.1016/S0304-405X(02)00249-0

25. Kane A., Marcus A.J., McDonald R.L. How Big is the Tax Advantage to Debt? The Journal of Finance, 1984, vol. 39, iss. 3, pp. 841-853. URL: https://doi.org/10.1111/j.1540-6261.1984.tb03678.x

26. Leland H.E. Corporate Debt Value, Bond Covenants, and Optimal Capital Structure. The Journal of Finance, 1994, vol. 49, iss. 4, pp. 1213-1252. URL: https://doi.org/10.1111/j.1540-6261.1994.tb02452.x

27. Post J., Preston L., Sachs S. Redefining the Corporation: Stakeholder Management and Organizational Wealth. Stanford, Stanford University Press, 2002, 376 p.

28. Myers S.C., Majluf N.S. Corporate Financing and Investment Decisions When Firms Have Information That Investors Do Not Have. Journal of Financial Economics, 1984, vol. 13, iss. 2, pp. 187-221. URL: https://doi.org/10.1016/0304-405X(84)90023-0

\section{Conflict-of-interest notification}

We, the authors of this article, bindingly and explicitly declare of the partial and total lack of actual or potential conflict of interest with any other third party whatsoever, which may arise as a result of the publication of this article. This statement relates to the study, data collection and interpretation, writing and preparation of the article, and the decision to submit the manuscript for publication. 